Bioelectrochemistry and Bioenergetics 6 (1979) 493-5018

J. Electroanal. Chem. 104 (I979) 493-508

(C) Elsevier Sequoia S.A., Lausanne - Printed in Italy

\title{
272 - Kinetic Model of a Depolarization-Type Bioelectrochemical Fuel Cell
}

\author{
by E. A. Di Salvo, H. A. Videla and A.J. Arvía \\ Instituto de Investigaciones Fisicoquímicas Teóricas y Aplicadas (INIFTA), \\ División Electroquímica, Sucursal 4, Casilla de Correo I6, I90o La Plata, Ar- \\ gentina
}

Revised manuscript received July Ist 1979

\section{Summary}

The present work concerns a depolarization type bioelectrochemical fuel-cell with a bioanode consisting of a Micrococcus cerificans/glucose resting-cell system. Its response is interpreted in terms of an oxygen supplying zone (electrode) and an oxygen-consuming zone (cellular mass) separated by the cell membrane areas. The influence of the substrate and microorganism concentrations in the kinetics of the overall process is evaluated, and the maximum efficiency for cell design is discussed.

\section{Introduction}

Biological fuel cells operate through the contribution of two electrochemical processes occurring simultaneously in different regions, one anodic and the other cathodic, with the participation of a living system either in both or in only one of them. The living system consists either of a growing cell suspension, or resting cells or an isolated enzymatic system. ${ }^{1-6}$ According to the biofuel cell classification made by GRAY YoUNG et $a l .,{ }^{7}$ the depolarization type bioelectrochemical fuel cell uses either a microorganism (growing cell suspension or resting cells) or enzymatic systems to depolarize one half-cell by consuming the oxygen formed at the anode while air or oxygen is supplied to the other half cell.

For biological fuel cell design the determination of the quantitative relationships among the different kinetic parameters of the bioelectrochemical system is required. ${ }^{8-18}$ The simplest type of biological fuel cell is the anodic depolarization biological fuel cell where the microorganism acts as a chemical depolarizer without interfering in the electrode processes. ${ }^{7}$ This type of cell can be coupled to non-continuous fermentative systems. ${ }^{19-21}$ 
The aim of the present study is to interpret the mechanism of a biological depolarization type fuel cell in terms of a resistor model involving the interdependence of the biological and electrochemical parameters. A resting cell system is particularly suitable for this purpose taking into account that biological variables involved (cell and substrate concentration) can be easily controlled.

\section{Experimental}

The schemes of the $\mathrm{H}$-type cell and of the auxiliary measurement circuits are depicted in Fig. I. The cell is made of Pyrex glass with ground glass joints. The anodic and cathodic compartments locate platinized platinum electrodes isolated by cellulose acetate membranes. The black Pt electrodes (ca. I0.5 $\mathrm{cm}^{2}$ apparent area) are anodized at $0.23 \mathrm{~A}$ during Io $\min$ in $2 \mathrm{~N} \mathrm{H}_{2} \mathrm{SO}_{4}$ at room temperature before each run. The composition of the electrolyte containing the cell suspension expressed in $\mathrm{g} / \mathrm{l}$ is: $\mathrm{NaCl}(0.2) ; \mathrm{MgSO}_{4} \cdot 7 \mathrm{H}_{2} \mathrm{O}$ (0.2); $\mathrm{KH}_{2} \mathrm{PO}_{4}$ (I); $\mathrm{K}_{2} \mathrm{HPO}_{4}$ (2) ; $\mathrm{Na}_{2} \mathrm{HPO}_{4}$ (I). The electrolyte is buffered at $\mathrm{pH} 7$.

The cell suspension of the anodic compartment is continuously pumped at $150 \mathrm{~cm}^{3} / \mathrm{min}$ through an $\mathrm{O}_{2}$-monitoring electrode. ${ }^{22,23}$ The potential vs. current relationships were obtained under constant load discharge conditions. The current $v$ s. time relationships were obtained by using a I0oo $\Omega$ external resistance between the anode and the cathode of the electrochemical cell. Under these circumstances it should be emphasized that, before each run, the working electrode pretreatment already referred was systematically repeated. Anodic and cathodic potentials are potentiometrically measured against saturated calomel electrodes (S.C.E.). The concentration of glucose is evaluated using the $o-$ toluidine method and the number of viable microorganisms is determined by plate-counting methods.

The cells are cultivated at $30^{\circ} \mathrm{C}$ on agar slant tubes with the addition of the electrolyte and yeast extract $(5 \mathrm{~g} / \mathrm{l}),\left(\mathrm{NH}_{4}\right)_{2} \mathrm{SO}_{4}$ ( $\left.\mathrm{I} .5 \mathrm{~g} / \mathrm{l}\right)$ and glucose $(4 \mathrm{~g} / \mathrm{l})$. After $24 \mathrm{hr}$ the cells are transferred to ERLENMEYER flasks under stirring. When the culture reaches the logarithmic region of the growth curve ( 4 to $5 \mathrm{hr}$ ), the cells are centrifugated and washed with the electrolyte before preparing the suspensions of different concentration.

The obligated aerobic M.c. strain is generally grown with insoluble carbon sources such as hydrocarbons, ${ }^{24-29}$ With this media, however, the determination of the number of cells is inaccurate. The M.c. strain is then successfully adapted to grow with soluble carbon sources such as glucose in the presence of yeast extract. A resting cells system without the addition of yeast extract is employed to keep a controlled cell concentration and to avoid turbidity changes of the medium. ${ }^{30}$ 


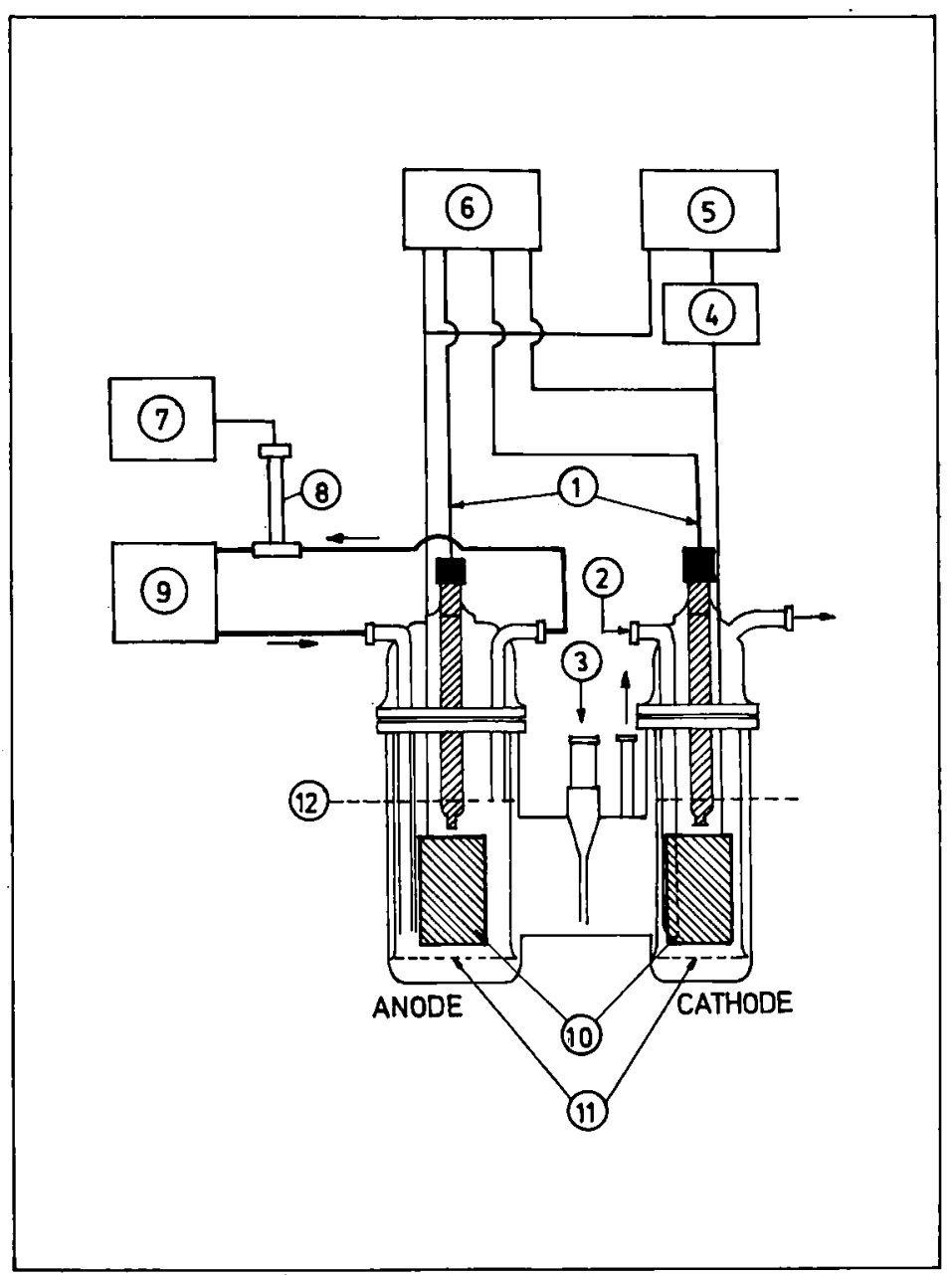

Fig. I.

Experimental set-up of cell and measurement circuitry. I : Calomel electrodes ; 2 : Oxygen inlet ; 3 : Nitrogen inlet; 4 : Charge resistor ; $5:$ Ammeter ; $6:$ Potentiometer ; $7: x-t$ recorder; 8: Oxygen probe; 9 : Peristaltic pump; 10: Platinized platinum electrodes; II : Cellulose acetate membranes; I 2 : Electrolyte level.

\section{Results}

The galvanic cell containing the sterile medium without glucose (blank) attains a residual current $\left(I_{0}\right)$ of $c a$. Io $\mu \mathrm{A}$. In the presence of glucose it decreases to $2 \pm 0.8 \mu \mathrm{A}$ remaining at this value for at least $24 \mathrm{hr}$. Under these circumstances the open circuit potential is $0.3 \pm$ 
$0.015 \mathrm{~V}$ (vs. S.C.E.). The electrolyte saturated with $\mathrm{O}_{2}$ at atmospheric pressure exhibits at $0.3 \mathrm{~V}$ an $\mathrm{O}_{2}$ limiting current equal to ro $\mu \mathrm{A}$, which is taken as the $100 \% \mathrm{O}_{2}$ threshold.

The resting cells are then added to the anodic compartment and left without glucose for $30 \mathrm{~min}$ (Fig. 2). Then, the experiment is initiated $(t=0)$ by adding different amounts of substrate to the system and following the changes of the electrochemical parameters and the $\mathrm{O}_{2}$ concentration, the latter decreasing very fast. The current $(I)$ reaches a maximum value $\left(I_{m}\right)$ decreasing afterwards linearly when the resting cells consume glucose and when the latter is depleted, the current approaches exponentially that of the blank. Otherwise, after the glucose addition, the concentration of dissolved $\mathrm{O}_{2}$ decreases to a low limiting value which depends only on the microorganism concentration and it

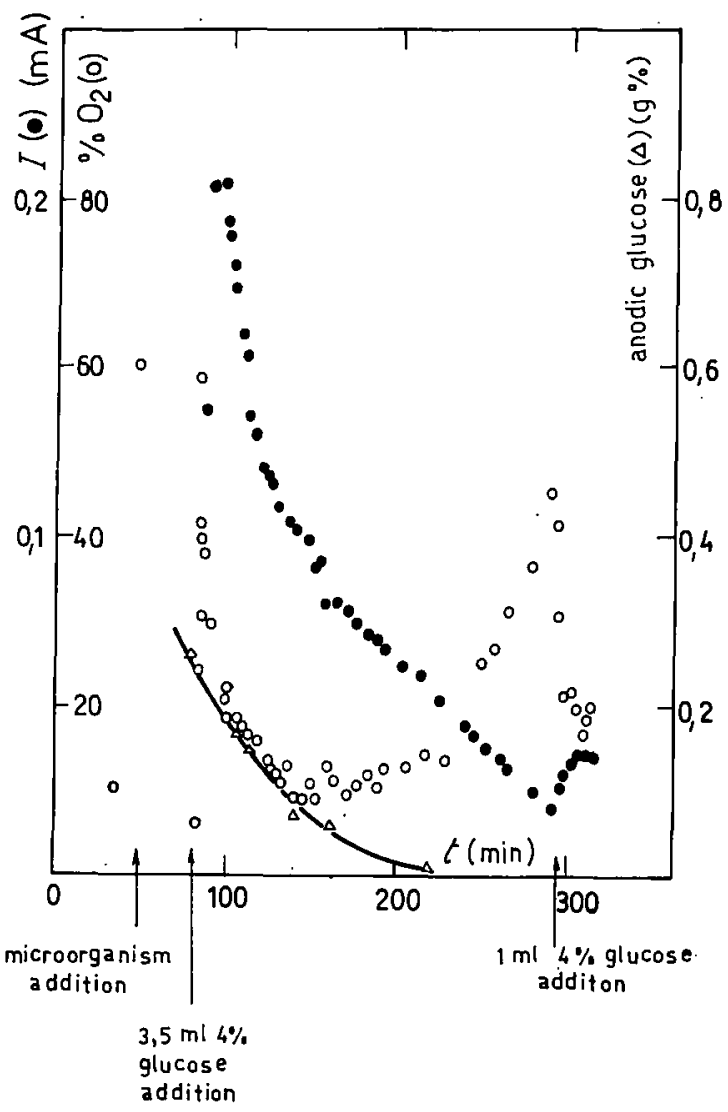

Fig. 2.

Time dependence of $I(0)$, oxygen percentage $(O)$ and anodic glucose concentration $(\Delta)$. Microorganism concentration: $3 \times 10^{7} \mathrm{cell} / \mathrm{cm}^{3}$. 
remains practically constant as long as glucose is present in the solution. When glucose is depleted, the $\mathrm{O}_{2}$ concentration increases to reach $c a$. $50 \% \mathrm{O}_{2}$ concentration at $294 \mathrm{~min}$. At this point a new addition of glucose is made and immediately a decrease of the $\mathrm{O}_{2}$ concentration is observed again. The anodic potential decreases as the current drawn from the biocell increases, otherwise, the cathodic potential remains practically unaltered.

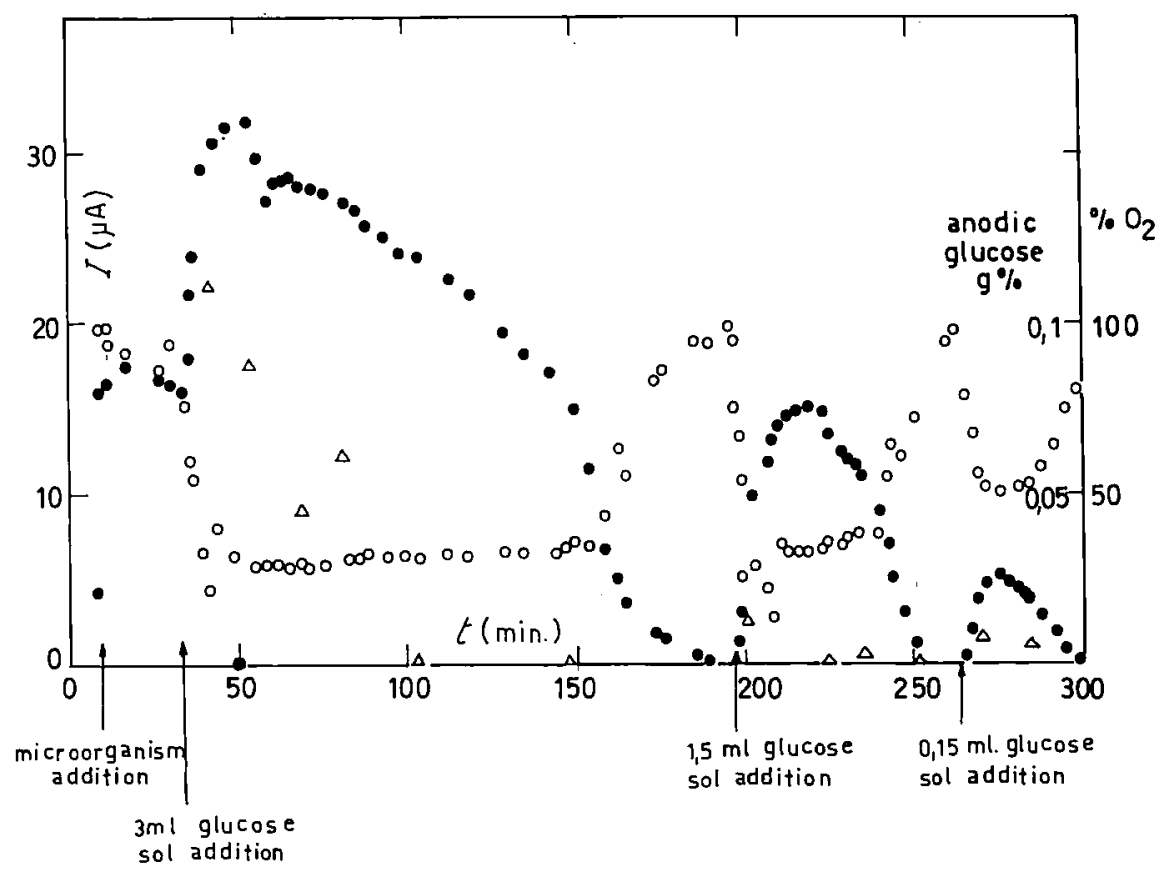

Fig. 3.

Repetitive experiments after successive glucose additions: (๑) $I$ vs. time; (O) $\% \mathrm{O}_{2}$ vs. time; $(\Delta) \%$ anodic glucose vs. time. Microorganism concentration : $6 \times 10^{6} \mathrm{cell} / \mathrm{cm}^{3}$.

Experiments made by adding new amounts of glucose to the exhausted medium show that in spite of the constant number of cells, the efficiency of the galvanic cell decreases after the successive glucose additions (Fig. 3). This is apparently related to the systematic damage of the biological material during the cell operation which cannot be attributed to a partial lysis of the cells.

The current drainage through the load resistance increases very remarkably when cells are added to the substrate as compared to the plain substrate solution. This clearly shows the importance of the biological agent in the performance of the electrochemical cell. Under each parti- 


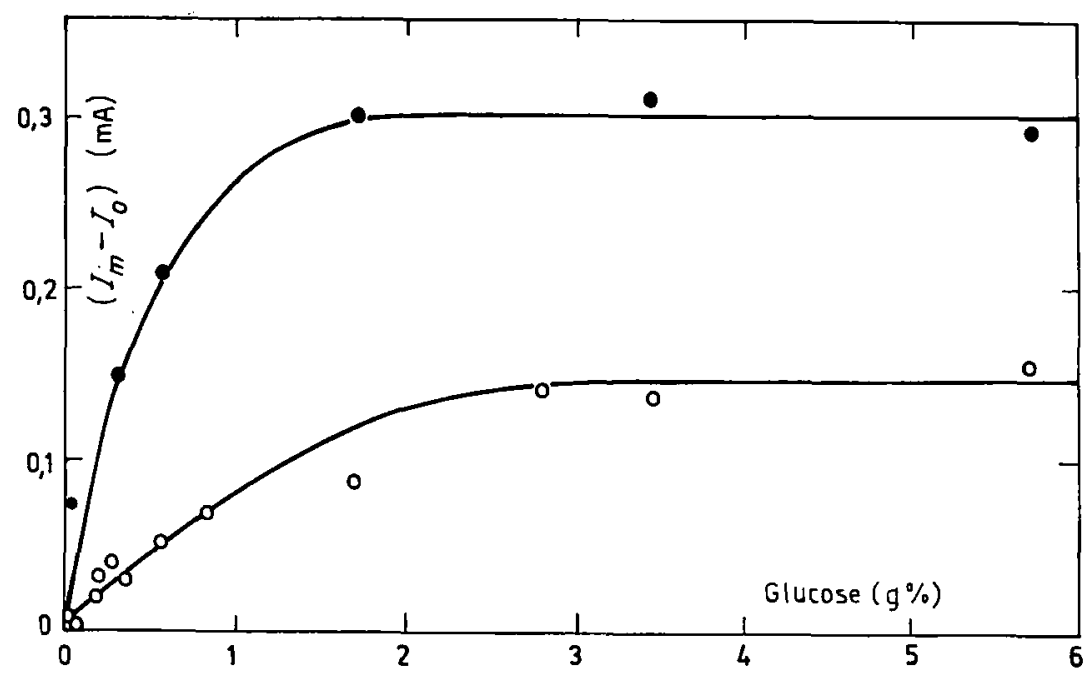

Fig. 4.

Maximum current $\left(I_{m}-I_{0}\right)$ vs. glucose concentration. Microorganism concentration : (O) $1.4 \times 10^{8} \mathrm{cell} / \mathrm{cm}^{3} ;$ (O) : $1.4 \times 10^{7} \mathrm{cell} / \mathrm{cm}^{3}$.

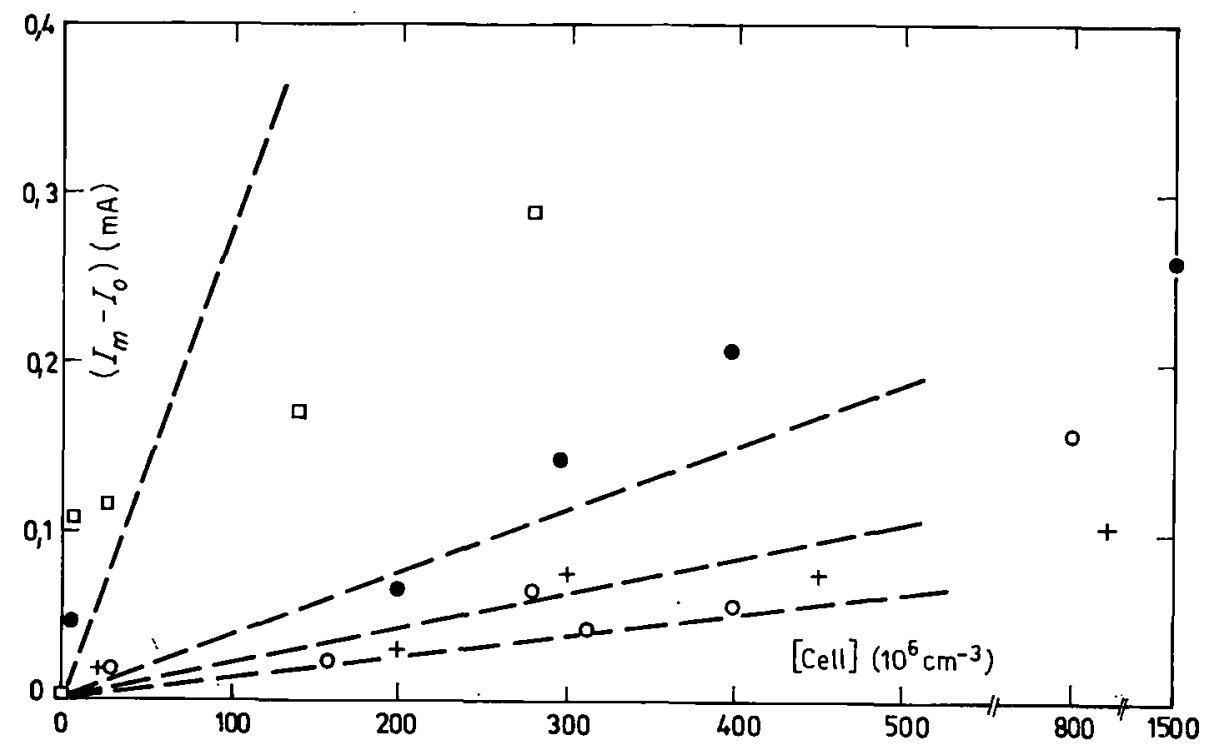

Fig. 5 .

Maximum current $\left(I_{m}-I_{\mathrm{o}}\right)$ vs. microorganism concentration. Initial glucose concentration [g]: (O) $0.129 \mathrm{~g} \%$; (+) $0.250 \mathrm{~g} \%$; (०) $0.363 \mathrm{~g} \%$; ( $\square$ ) $3.5 \mathrm{~g} \%$. 
cular set of experimental conditions, due to the gradual deterioration of the biological system, the maximal current value was taken as a measure of the electrochemical cell performance.

Other types of experiments are made, namely, those with a constant number of cells and a variable concentration of glucose and those with a constant glucose concentration and different microorganism concentrations (Figs. 4-5). To avoid irreproducibility derived from the different inocula a liquid culture previously obtained from a $24 \mathrm{hr}$ culture tube at $30^{\circ} \mathrm{C}$ is used. Control experiments show no appreciable cell damage in the diluted media before adding the cells to the bioanode compartment.

For a constant glucose concentration the current maximum and the rate of $\mathrm{O}_{2}$ consumption depend directly of the microorganism concentration (Fig. 6).

After reaching $I_{m}$, a linear $\log I$ vs. time relationship is observed which holds until the $\mathrm{O}_{2}$ concentration at the bioanode begins to increase due to glucose depletion. The time to attain the maximum current depends inversely on the glucose concentration and on the microorganism concentration (Table I).

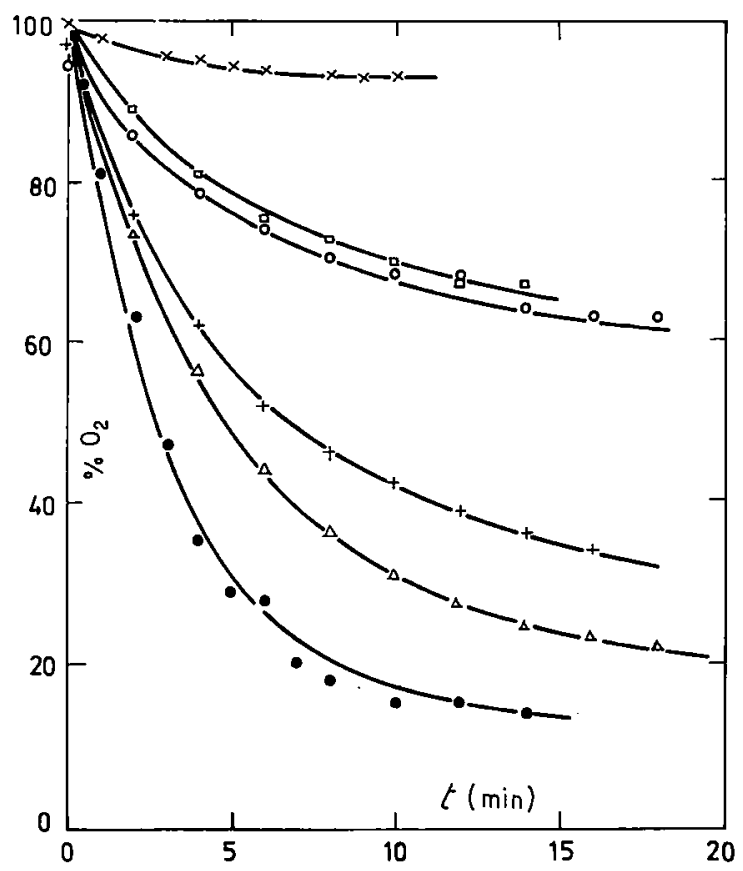

Fig. 6 .

Time dependence of the oxygen concentration for different microorganism concentrations : (ब) $\mathrm{I} .5 \times \mathrm{IO}^{8} \mathrm{cell} / \mathrm{cm}^{3} ;(\Delta) 4 \times 10^{8} \mathrm{cell} / \mathrm{cm}^{3} ;(+) 3 \times 10^{8} \mathrm{cell} / \mathrm{cm}^{3} ;$ (O) $2.8 \times 10^{8} \mathrm{cell} / \mathrm{cm}^{3}$; ( $\square$ ) $2 \times \mathrm{IO}^{8} \mathrm{cell} / \mathrm{cm}^{3} ;(X) 2.9 \times 10^{6} \mathrm{cell} / \mathrm{cm}^{3}$. Initial glucose concentration $\left[G_{\mathrm{o}}\right]: 0.363 \mathrm{~g} \%$. 
Table I. Time to reach $I_{m}$ counted from $t=0$ for different glucose and cell concentrations.

\begin{tabular}{|c|c|c|}
\hline $\begin{array}{c}\text { Initial glucose } \\
\text { concentration } \\
(\mathrm{g} \%)\end{array}$ & $\begin{array}{l}\text { Cell concentration } \\
\left(\text { cells } / \mathrm{cm}^{3}\right)\end{array}$ & $\begin{array}{c}\text { Time to reach } I_{m} \\
\text { (min) }\end{array}$ \\
\hline $\begin{array}{l}0.3^{6} 3 \\
0.3^{6} 3 \\
0.3^{6} 3 \\
0.3^{6} 3 \\
0.3^{6} 3\end{array}$ & $\begin{array}{r}4 \times 10^{8} \\
3 \times 10^{8} \\
2.8 \times 10^{8} \\
2 \times 10^{8} \\
2.9 \times 10^{6}\end{array}$ & $\begin{array}{l}20 \\
\text { I } 5.8 \\
\text { I } 5.8 \\
\text { I } 1.5 \\
7.6\end{array}$ \\
\hline $\begin{array}{l}5.7 \text { I } 4 \\
3.425 \\
1.7 \text { I } 4 \\
0.57 \mathrm{I} \\
0.307 \\
0.057\end{array}$ & $\begin{array}{l}1.4 \times 10^{8} \\
1.4 \times 10^{8} \\
1.4 \times 10^{8} \\
1.4 \times 10^{8} \\
1.4 \times 10^{8} \\
1.4 \times 10^{8}\end{array}$ & $\begin{array}{l}8.5 \\
6 \\
7.2 \\
\text { IO } \\
\text { I I } \\
\text { I } 2\end{array}$ \\
\hline
\end{tabular}

The current $v s$. potential ( $I$ vs. $U$ ) plot (Fig. 7) was obtained differently from the conventional polarization curves. In this case a constant charge resistor (I00o $\Omega$ ) was used to record the $U$ vs. $t$ and the $I$ vs. $t$ displays. The pair of the instantaneous $I-U$ values were read from the $U-t$ plot and from the $I-t$ plot at different $t$. The $I$ vs. $U$ plot, therefore, reflects the whole evolution of both the biological and the electrochemical systems. Thus, under working conditions the bioanode potential becomes more negative than the corresponding equilibrium potential. The $I$ vs. $U$ plot apparently shows a predominantly ohmic-type behaviour. The increase of microorganism concentration shifts the bioanode potential towards more negative potentials as it would be expected for a decrease of the oxygen concentration due to the presence of the microorganism. For a microorganism concentration lower than $5 \times 10^{7}$ cells per $\mathrm{cm}^{3}$ the current depends linearly both on the glucose and on the microorganism concentrations (Fig. 8). For glucose concentrations lower than I.5 g/l, $I_{m}$ also depends linearly on glucose concentration (Fig. 4). At higher concentrations a saturation effect is observed indicating that the bioelectrochemical process is controlled by the microorganism concentration.

It is noteworthy that the cell response is only achieved whenever microorganisms, substrate and oxygen are present. Only under these circumstances the bioelectrochemical reaction takes place. This discards the possible discharge of glucose as being the responsible of the cell potential. ${ }^{31}$ 


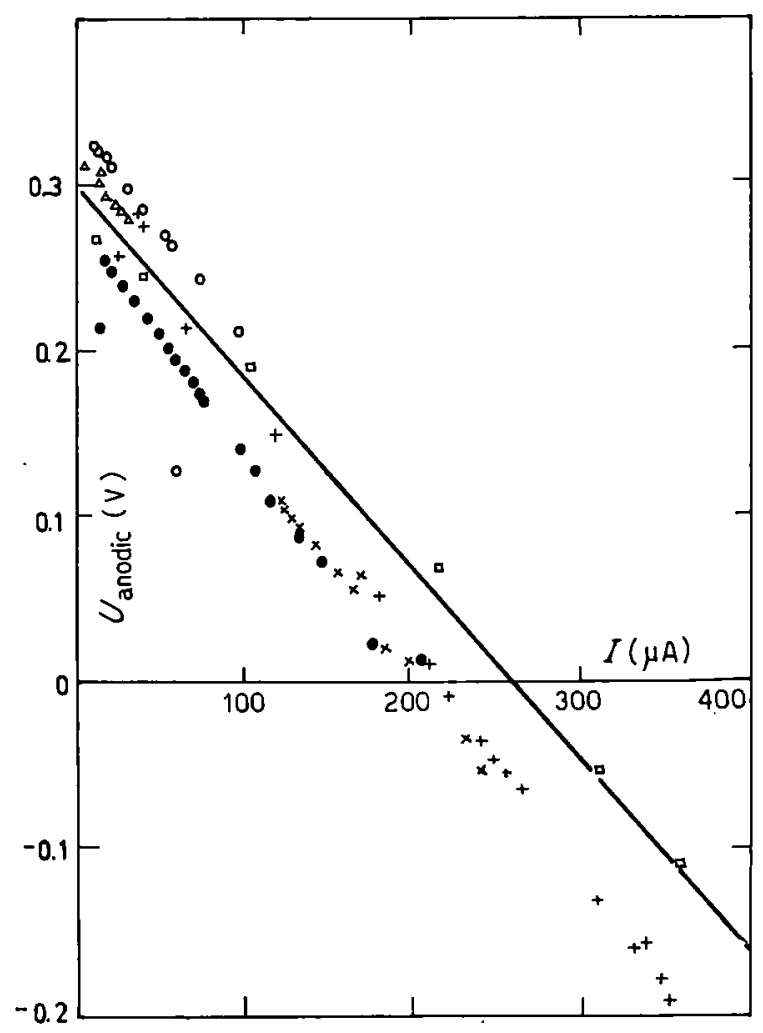

Fig. 7.

Anodic potential vs. $I$ plot. (O) microorganism concentration : $3 \times 10^{7} \mathrm{cell} / \mathrm{cm}^{3}$, initial glucose concentration $\left[\mathrm{g}_{0}\right]: 0.26 \mathrm{~g} \% ;(0) 9.6 \times 10^{6} \mathrm{cell} / \mathrm{cm}^{3}$ and $0.23 \mathrm{~g} \% ;(\Delta) 7.7 \times 10^{6}$ cell $/ \mathrm{cm}^{3}$ and $0.28 \mathrm{~g} \% ;(+) 9.2 \times 10^{6} \mathrm{cell} / \mathrm{cm}^{3}$ and $0.6 \mathrm{~g} \% ;(X) 3.5 \times 10^{8} \mathrm{cell} / \mathrm{cm}^{3}$ and $0.19 \mathrm{~g} \%$. (口) Estimated values.

\section{Discussion}

\section{The possible kinetic control at the bioanode}

The foregoing results show that at the bioanode the current output involves both glucose and $\mathrm{O}_{2}$ consumption and depends on the cell per $\mathrm{cm}^{3} \mathrm{~N}$ and glucose concentration [g]. The overall anodic process involves the rate of transport of $\mathrm{g}$ and $\mathrm{O}_{2}$ through the different physical and biological interfaces. The complementary reaction at the cathode is attributed to the electroreduction of $\mathrm{O}_{2}$.

From the kinetic standpoint the bioelectrochemical process at the bioanode involves three regions, namely, the electrode/electrolyte interface acting as the electrochemical $\mathrm{O}_{2}$ supply region, the microorganism 


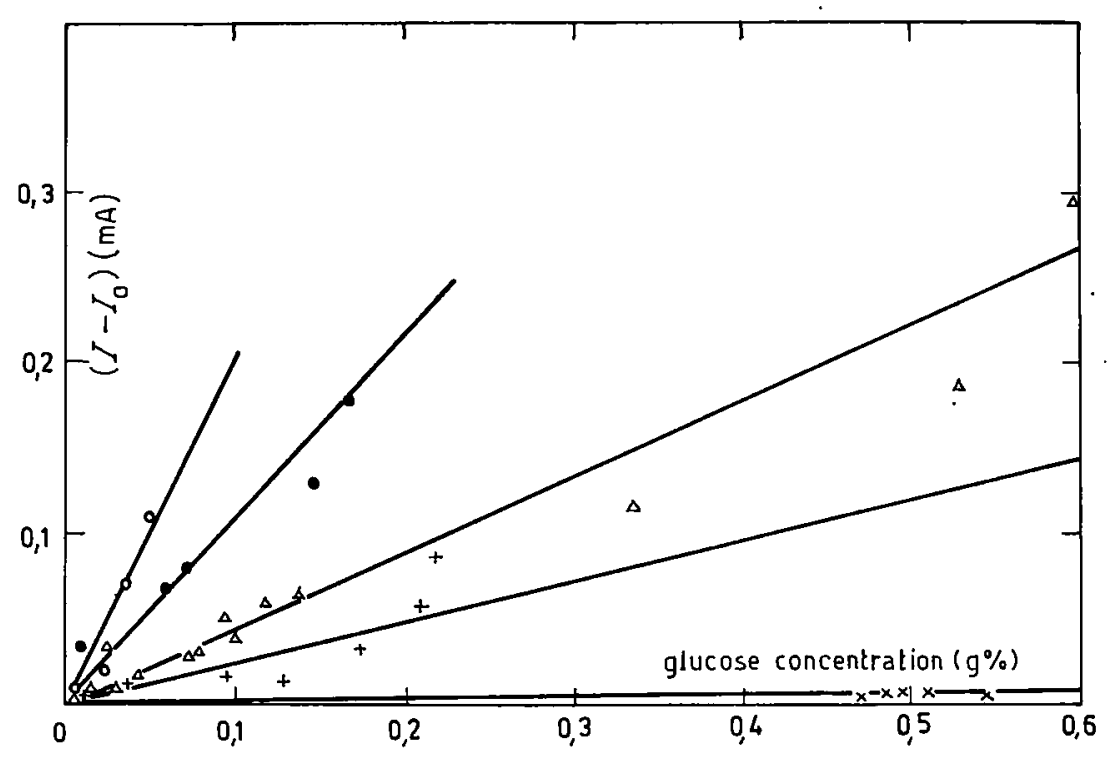

Fig. 8.

Current substrate concentration relationships. Microorganism concentration : $(X) 2 \times 10^{6}$ cell $/ \mathrm{cm}^{3} ;(\Delta) 9.2$ to $9.6 \times 10^{6} \mathrm{cell} / \mathrm{cm}^{3} ;(+) 7.7 \times 10^{6} \mathrm{cell} / \mathrm{cm}^{3} ;$ (O) $3 \times 10^{7} \mathrm{cell} / \mathrm{cm}^{3}$; (O) $3.5 \times 10^{8}$ cell $/ \mathrm{cm}^{3}$.

mass which is the $\mathrm{O}_{2}$ consumption region and the cell membranes. The substance itself cannot be considered responsible for the current production because in the absence of the bacteria practically no current is produced. ${ }^{31}$ Under limiting circumstances the anodic process may be rate controlled either by the electrochemical reaction or by the biological process itself. Under intermediate conditions the cell behaves as an oxygen concentration type cell where the electrochemical reaction at the anode is assisted by a biological agent (M). Thus,

$$
2 \mathrm{OH}^{-}+\mathrm{M} \stackrel{\mathrm{I} / R_{1}}{\longrightarrow} \mathrm{H}_{2} \mathrm{O}+\frac{\mathrm{I}}{2} \mathrm{O}_{2}+\mathrm{M}^{\prime}+2 \mathrm{e}^{-}
$$

and for the cathode:

$$
\frac{\mathrm{I}}{2} \mathrm{O}_{2}+\mathrm{H}_{2} \mathrm{O}+2 \mathrm{e}^{-} \rightarrow 2 \mathrm{OH}^{-}
$$

where $\mathrm{M}$ yields $\mathrm{M}^{\prime}$ during the anodic reaction and $\mathrm{I} / R_{1}$ represents the reaction rate of the anodic step (I) and $R_{1}$ stands for the specific reaction resistance. The latter consists at least of the transport of the reactive species from the bulk of the solution towards the electrochemical interface 
at the rate $v_{1}$, the proper electrochemical reaction yielding $\mathrm{O}_{2}$ at the rate $v_{2}$, and the transport of reaction products from the electrochemical interface outwards at the rate $v_{3}$. If either $v_{1}$ or $v_{3}$ are smaller than $v_{2}$, the rate of the reaction (I) becomes rate-determining by the transport of reacting species either from or towards the electrochemical interface. ${ }^{32}$

The biological process involves the transport of $\mathrm{O}_{2}$ and $\mathrm{g}$ through the cellular membrane to the interior of the cells. These transport processes occur through the two interfaces of the cellular membrane. Thus, at the outer solution/membrane interface $\mathrm{O}_{2}$ and $\mathrm{g}$ are transferred from the solution, namely:

$$
\begin{aligned}
& \mathrm{O}_{2} \text { (solution) } \stackrel{\mathrm{I} / R_{2}}{\rightarrow} \mathrm{O}_{2} \text { (membrane) } \\
& \mathrm{g} \quad \text { (solution) } \stackrel{\mathrm{x} / R_{3}}{\Rightarrow} \mathrm{g} \quad \text { (membrane) }
\end{aligned}
$$

The transport of $\mathrm{g}\left(R_{4}\right)$ and $\mathrm{O}_{2}\left(R_{5}\right)$, through the cellular membrane is produced by the corresponding concentration gradients across the membrane. The glucose transport is probably related to a facilitated diffusion process. $^{33,34}$ At the membrane /inner solution interface the corresponding transport phenomena can be expressed as follows:

$$
\begin{aligned}
& \mathrm{O}_{2} \text { (membrane) } \stackrel{\mathrm{I} / R_{8}}{\Rightarrow} \mathrm{O}_{2} \text { (cell interior) } \\
& \mathrm{G} \text { (membrane) } \stackrel{\mathrm{I} / R_{7}}{\Rightarrow} \mathrm{G} \text { (cell interior) }
\end{aligned}
$$

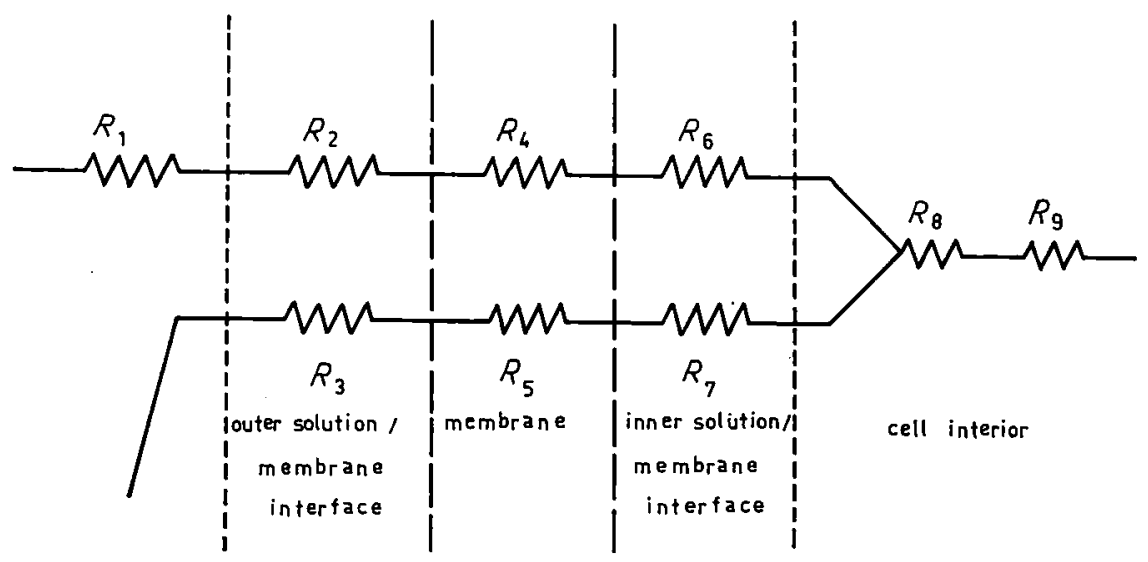

Fig. 9.

Simple equivalent circuit for the bioanode. 
Finally, inside the cell, the g oxidation is biologically accomplished. The total biological reaction is:

$$
\mathrm{g}+\mathrm{O}_{2}+\text { Enzimatic system } \stackrel{\mathrm{I} / R_{\mathrm{g}}}{\rightrightarrows} \text { Oxidation products, }
$$

the reaction products diffusing out :

$$
\begin{gathered}
\text { Oxidation products } \\
\text { (cell interior) }
\end{gathered} \stackrel{\mathrm{I} / R_{9}}{\longrightarrow} \quad \begin{gathered}
\text { Oxidation products. } \\
\text { (cell exterior) }
\end{gathered}
$$

Therefore, the bioelectrochemical reaction can be conceived as the sum of successive stages which are represented by an equivalent electrical circuit (Fig. 9). The current output through this circuit depends on the sum $\sum_{i} R_{i}$, including $R_{c}$, the internal galvanic cell resistance. The kinetic analysis involves various limiting cases which are considered below disregarding for the moment any ohmic-type polarization.

When $R_{1} \gg \sum_{i=2}^{n} R_{i}$, the rate of the reaction at the bioanode is the rate determining step and this implies either a net electrochemical activation control or a diffusion control due either to the reacting species or to the reaction products. In the former case, the rate of either reactions (I) or reaction $\left(\mathbf{I}^{\prime}\right)$ fit the kinetic laws of activated processes namely ${ }^{23}$

$$
I_{a}=k^{\prime} A \quad c_{\mathrm{M}^{\mathrm{x}}} c_{\mathrm{OM}} \mathrm{y}-\theta \exp \left(\frac{\alpha_{a} F \eta_{a}}{R T}\right)
$$

or

$$
I_{c}=k^{\prime \prime} A(I-\theta) p_{\mathrm{O}_{2}}{ }^{2} \exp \left(\frac{\theta_{c} \boldsymbol{F} \eta_{c}}{R T}\right)
$$

respectively, where $k^{\prime}$ and $k^{\prime \prime}$ are formal rate constants, $A$ is the electrode area, the $\eta$ 's are the charge transfer overpotentials referred to the $\mathrm{O}_{2}$ reversible electrode, the $\alpha$ 's are the transfer coefficients assisting the reaction either in the anodic $(a)$ or in the cathodic $(c)$ direction, $\theta$ is the degree of electrode area available, the $c$ 's refer to the concentrations at the electrode surface of the species indicated by the subindices, $p$ denotes the oxygen gas pressure ad $x, y$ and $z$ are the corresponding reaction orders. The charge transfer overpotentials, in the case of the oxygen electrode are the kinetically deciding parameters.

If $R_{1} \ll \sum_{i=2}^{n} R_{i}$, the resistance of the electrochemical $\mathrm{O}_{2}$ production is smaller than the resistance of any of those processes involving the $\mathrm{O}_{2}$ consumption by the biological system. Then, the metabolic characteristics of the biological species regulates the $\mathrm{O}_{2}$ level in the system. 
Under quasi-stationary state the amount of $\mathrm{O}_{2}$ generated at the electrode equals the amount of $\mathrm{O}_{2}$ incorporated to the cellular mass. Therefore, the corresponding fluxes, respectively $\boldsymbol{J}_{\mathrm{O}_{2, \mathrm{e}}}$ and $\boldsymbol{J}_{\mathrm{O}_{2, c}}$ are equal. Under these circumstances the rate of $\mathrm{O}_{2}$ electroformation can be expressed by means of the simple convective-diffusion equation:

$$
\boldsymbol{J}_{\mathrm{O}_{2, \mathrm{e}}}=D_{\mathrm{O}_{2}} \frac{c_{\mathrm{O}_{2, \mathrm{e}}}-c_{\mathrm{O}_{2, s}}}{\delta_{N}}=\boldsymbol{J}_{\mathrm{O}_{2, \mathrm{c}}}
$$

where $c_{\mathrm{O}_{2, \mathrm{e}}}$ is the $\mathrm{O}_{2}$ concentration at equilibrium determining the bioanode potential, $c_{\mathrm{O}_{2, s}}$ is the saturation concentration and $\delta_{N}$ is the apparent diffusion layer thickness. Independently of the controlling step, the $\mathrm{O}_{2}$ and the $g$ fluxes at the outer solution |membrane interface, at the membrane|inner solution interface are equal :

$$
J_{R_{2}}=J_{R_{4}}=J_{R_{6}}=J_{R_{8}}=J_{R_{9}}
$$

These fluxes may be expressed by an equation such as:

$$
\boldsymbol{J}_{\boldsymbol{i}}=k_{i} A^{\prime} \Delta c_{i}
$$

where $A^{\prime}$ is the total membrane area available which is proportional to $N$, and $k_{i}$ is the permeability coefficient of the $i$-species

$$
k_{i}=\frac{D_{i} \beta_{i}}{l} .
$$

where $D_{i}$ is the diffusion coefficient at the membrane; $\beta_{i}$ is the partition coefficient, and $l$ is the average membrane thickness.

In the interior of the cell, the combustion reaction is a function of both the cellular $g$ concentration and the $\mathrm{O}_{2}$ concentration. For the overall process, expressed by $\boldsymbol{J}_{8}$, independently of the consecutive processes of $\mathrm{g}$ incorporation and oxidation, it can be assumed that the enzyme system involved in reaction (8) is in the neighborhood of the membrane. Then, $c_{g, \text { cell }}=c_{g, e}$ and the total reaction pathway can be concisely expressed by

$$
\mathrm{g}+\mathrm{E}+\frac{\mathrm{I}}{2} \mathrm{O}_{2} \rightarrow \mathrm{gE}+\frac{\mathrm{I}}{2} \mathrm{O}_{2} \rightarrow \mathrm{E}+\text { Products. }
$$

where $\mathrm{E}$ represents the enzymatic system participating in the glucose oxidation.

The cellular combustion fits the Michaelis-Menten equation :

$$
\boldsymbol{J}_{\mathrm{B}}=\frac{N \boldsymbol{J}_{8, \max } c_{g, \mathrm{e}}}{K_{M}+c_{g, \mathrm{e}}}
$$


where $K_{M}$ is the reciprocal of a complex affinity constant involving $\mathrm{g}$ input and conversion. Hence, under a quasi-stationary state $\boldsymbol{J}_{8}=\boldsymbol{J}_{\mathrm{O}_{2}}$ and the rate of $\mathrm{O}_{2}$ production at the electrode is controlled by the conversion of $g$ to products in the interior of the cell.

\section{Kinetic interpretation of the cell response}

The steady current, $I$, floxing through the cell can be expressed either in terms of $\mathrm{O}_{2}$ production or cellular combustion :

$$
I=n \boldsymbol{F} A \boldsymbol{J}_{\mathrm{O}_{2}}=\frac{N \boldsymbol{J}_{8, \max } c_{g, e}}{K_{M}+c_{g, e}}
$$

where $n$ is the number of charges per mole of reacting species, and $\boldsymbol{F}$ is the FARADAY constant. For the system involving a large $N$, before $g$

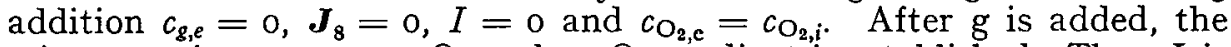
microorganism consumes $\mathrm{O}_{2}$ and an $\mathrm{O}_{2}$ gradient is established. Then $I$ is given by :

$$
I=n \boldsymbol{F} A N k_{\mathrm{O}_{2}} \Delta c_{\mathrm{O}_{2}} \text {. }
$$

Depending on the amoung of g added, $c_{g, e} \gtrless K_{M}$. When $c_{g, e} \gg K_{M}$, $I_{m}$, independently of the $\mathrm{g}$ concentration, $\boldsymbol{J}_{\mathbf{8}}=\boldsymbol{J}_{8, \max }$ and $\Delta c_{\mathrm{O}_{2}}=$ const. When $c_{g, e} \ll K_{M}, I$ depends on the g concentration and, under steady state conditions, it is linearly related to $c_{g}$.

For a constant $N$, once $\mathrm{g}$ is depleted, a new addition of $\mathrm{g}$ implies that the current again increases to attain a new steady state. Then, the shorter the time required for attaining $I_{m}$, the larger the $[\mathrm{g}] / N$ ratio. For a particular $g$ concentration, the slope of the percentage of dissolved $\mathrm{O}_{2}$ vs. time relationship depends only on $N$ and the slope of the $I_{m} v s$. $N$ plot depends on the external $\mathrm{g}$ concentration. If the current output is low and the $\mathrm{O}_{2}$ uptake by the microorganism becomes larger than the contribution of the electrochemical reaction the rate is controlled by the dissolved $\mathrm{O}_{2}$ concentration. When $N$ is large, the $\mathrm{O}_{2}$ transport from the electrode or the $g$ transport to the cellular mass results scanty influenced by the viscosity variation, since the latter enters the kinetic equation just with a I/6th exponent. ${ }^{32}$

A deviation from the linear relationship when $N$ is high may probably be due to a diminution of the active membrane area $\left(A^{\prime}\right)$ by the increasing cell contacts which affects directly the $\mathrm{g}$ and $\mathrm{O}_{2}$ transport. This effect is partially compensated by stirring.

The total overpotential $\left(\eta_{T}\right)$ of the working biocell can be expressed as the sum of the charge transfer $\left(\eta_{a}\right)$, concentration $\left(\eta_{c}\right)$ and ohmic $\left(\eta_{0}\right)$ overpotentials. For the ohmic cell resistance, however $\left(R_{c}=I_{500} \Omega\right)$, the biological fuel cell response depends markedly on the ohmic overpotential. For low values of $R_{c}$ the current depends linearly on the microorganism concentration and on the concentration of the oxidizable substrate. On the other side, each biological species has its own maximum 
rate of consumption at a critical concentration. Therefore, to achieve such a situation when designing a depolarization type bioelectrochemical fuel cell, there is an optimal cell concentration for which the cell membrane area restriction by contact between microorganism is avoided. For this type of depolarization bioelectrochemical fuel cell the oxidizable substrate must produce under its metabolic pathway the larger oxygen uptake.

\section{Acknowledgments}

The Institute (INIFTA) is patronized by the following Institutions: Universidad Nacional de La Plata, Consejo Nacional de Investigaciones Científicas y Técnicas and Comisión de Investigaciones Científcas (Pcia. de Bs.As.). This work was partially supported by the Regional Program for the Scientific and Technological Development of the Organisation of the American States.

\section{References}

1 M.G. Del Duca and J.M. Fuscoe, Int. Sci. Technol. 39 (I965) 56

2 J.O'M. Bockris and S. SRINIVASAN, Fuel Cells. Their Electrochemistry; Mc Graw-Hill, New York (1969)

3 F.W. Cope, Biological Interfaces Behave Like Electrode Surfaces, Workshop in Bioelectrochemistry, Princeton, N.J. (r97 I)

4 M. Cener, Chem. Listy 62 (I968) 927

5 M.J. Allen and A.T. Yahiro, Electrochim. Acta 8 (I963) 4I9

6 F. Takahashi, M. Aisawa, J. Mizuguchi and S. Suzuki, Kogyo Kagaku Zasshi 73 (1970) 908

7 T. Gray-Young, L. Hadjipetrou and M.D. Lilly, Biotechnol. Bioeng. 8 (I966) $58 \mathrm{I}$

8 M.J. Allen and M. Nicholson, Electrochim. Acta 8 (I963) 820

9 J. Mrzuguchi, S. Suzuki and F. Takahashi, Bull. Tokyo Inst. Technol. 78 (I 966$) 27$

10 F. Takahashi, M. Aisawa, J. Mizuguchi and S. Suzuki, Kogyo Kagaku Zasshi 73 (1970) 912

11 B. Cohen, J. Bacteriol. 18 (I93I) 2 I

12 F.D. Sisler, Progress in Industrial Microbiology, Churchill, London (197r) Vol. 9, p. I

13 M.J. Allen, R.J. Bowen, M. Nicholson and B.M. Vasta, Electrochim. Acta 8 (1963) 99 I

14 M.J. Allen and R.L. Januszeski, Electrochim. Acta 9 (I964) I423

15 M. J. Allen, Electrochim. Acta 9 (1964) 1429

16 M.J. Allen, Electrochim. Acta 11 (1966) I

17 M.J. Allen, Electrochim. Acta 11 (I966) 7 
M.J. Allen, Electrochim. Acta 11 (1966) I 5

H.A. Videla and A.J. Arvia, Experientia Suppl. 18 (I97I) 067

H. Videla and A.J. Arvia, Anal. Asoc. Quim. Arg. 64 (1976) 85

21 H.A. Videla and A.J. Arvia, Biotechnol. Bioeng. 17 (I975) 1529

22 M. J. Johnson, J. Borkowski and C. ENGBlom, Biotechnol. Bioeng. 6 (1964) 457

23 E.A. Disalvo, Doctor's Degree Thesis, Fac. Ciencias Exactas, Univ. Nac. La Plata (I974).

24 R.F. Segovia, Doctor's Degree Thesis, Fac. Ciencias Exactas, Univ. Nac. La Plata (I97I)

25 J.E. Stewart, R.E. Kallio, D.P. Stevenson, A.C. Jones and D. Schissler, J. Bacteriol. 78 (I959) 44 I

26 A.P. Balatti, L.A. Mazza, R.F. Segovia and J. Ertola, Ion 30 (I97I) 3

27 R.A. Makula and W.R. Finnerty, J. Bacteriol. 103 (I970) 348

28 E.J. McKenna and R.E. Kallio, Annu. Rev. Microbiol. 19 (I965) I83

29 R.E. Mc Caman and W.R. Finnerty, J. Biol. Chem. 243 (I968) 5074

30 E.A. Disalvo and H.A. Videla, Anal. Asoc. Quim. Arg. 64 (1976) 259

31 I. Karube, T. Matsunaga, S. Tsura and S. Suzumi, Biotechnol. Bioeng. 19 (I977) I 727

32 A.J. Arvía and S.L. Marchiano, Los Fenómenos de Transporte en Electroquimica, Comisión de Investigaciones Científicas de la Prov. de Bs.As., La Plata (I972)

33 M. CeREIJIDo and C. Rotunno, Introducción al Estudio de las Membranas Biológicas, Editorial Universitaria, Buenos Aires (I966)

34 W.D. Stein, Theoretical and Experimental Biology, Academic Press Inc., London (1967) Vol. 6 